\title{
FREQUENCY OF HBV, HCV, AND HIV AMONG INJECTION DRUG USERS (IDUS), AND CO-RELATION WITH SOCIOECONOMIC STATUS, TYPE USE AND DURATION OF SUBSTANCE USE.
}

\author{
1. MBBS, FCPS \\ Assistant Professor \\ Isra University Karachi Campus. \\ Al-Tibry Medical College and \\ Hospital, Karachi, Pakistan. \\ 2. MBBS, FCPS Trainee \\ Department of Psychiatry and \\ Behavioral Sciences \\ JPMC (Jinnah Postgraduate Medical \\ Centre) Karachi, Pakistan.
}

Correspondence Address:

Dr. Muhammad Ilyas Jat

Department of Medicine and Allied.

Isra University Karachi Campus

(Al-Tibry Medical College and Hospital,

Karachi, Pakistan).

ilyas.jat84@gmail.com

Article received on:

28/07/2018

Accepted for publication:

22/12/2018

Received after proof reading:

25/06/2019

\section{Muhammad Ilyas Jat ${ }^{1}$, Ghulam Rasool Rind ${ }^{2}$}

ABSTRACT... Psychoactive drug use is a continual and chronic psychological and physical disease that is characterized by persistent substance use, regardless of detrimental results. Hepatitis B, C and HIV infections constitute serious healthcare issues worldwide. To determine the frequency of HBV, HCV, and HIV among Injection Drug Users (IDUs), visiting a tertiary care centre at Karachi, Pakistan, co-relation with socioeconomic status, type of substance use and duration of substance use. Study Design: A descriptive cross-sectional study. Setting: Psychiatry Outpatient Department (OPD), Department of Psychiatry and Behavioral Sciences, JPMC, Karachi. Period: $5^{\text {th }}$ Aug 2016 to $5^{\text {th }}$ Feb 2017. Material and Methods: Total 280 cases of both genders having Injection Drug Use history were enrolled in the study. Non-probability (consecutive) sampling was done. The data was analysed on SPSS version 20.0. Results: The average age of patients was $32.26 \pm 9.83$ years. Majority $256(91.4 \%)$ were male. Out of 280 , $142(50.7 \%)$ were married, $108(38.6 \%)$ were single, $20(7.1 \%)$ were widow and $10(3.6 \%)$ were divorced/separated. Most of patients belonged to lower socioeconomic class. Opioids were the most common substance used and most of patients were using substance for more than 2 years. Majority of patients were preliterate or educated till primary and were jobless. HCV was predominantly present followed by HBV, HIV as 47 (16.8\%), 22 (7.9\%) and 9 (3.2\%) respectively. Conclusion: Frequency of infections with HBV, HCV and HIV is quite high and alarming.

Key words: $\quad$ HBV, HCV, HIV, Injection Drug Use, Blood borne.

Article Citation: Jat MI, Rind GR. Frequency of hbv, hcv, and hiv among injection drug users (idus), and co-relation with socioeconomic status, type use and duration of substance use.Professional Med J 2019; 26(7):1147-1150.

DOI: 10.29309/TPMJ/2019.26.07.3788

\section{INTRODUCTION}

Psychoactive substance utilize is a continuous and reoccurring mental and physical disorder, portrayed by constant and over the top substance taking conduct and utilize, independent of unfavourable outcomes. It is seen as a mind related problem as psychoactive substances change the brain function; alter its structure and influence its capacities. These mind changes can be continuing on and can provoke various risky and blocking hones. ${ }^{1}$ Hepatitis B Infection (HBV), Hepatitis C Infection (HCV) and Human Insusceptible insufficiency Infection (HIV) pollutions constitute certified social protection issues the world over. HBV and HCV pollutions can achieve steady liver infections, including cirrhosis and hepatocellular carcinoma, while HIV illness can realize genuine sharp and deadly diseases. ${ }^{2}$ As showed by world wellbeing association (WHO), more than 240 million people with HBV illness and 150 million people with HCV defilement, have consistent liver related issues world-wide. . $^{3,4}$ There were around 35.3 million individuals tainted with HIV in $2012^{5}$ and $10 \%$ of the patients with HIV disease in Europe and America are co-contaminated with $\mathrm{HBV}$, and about $33 \%$ of the patients with HIV infection are co-tainted with HCV. $^{6}$ Injection drug use has been accepted a basic part in parenteral transmission of $\mathrm{HCV}, \mathrm{HBV}$, and HIV. Numerous investigations have depicted high commonness of antibodies to HCV (hostile to HCV) and hepatitis B centre antigen (against $\mathrm{HBc}$ ) among injection drug use clients (IDUs) in the United States and other countries ${ }^{7}$ and have estimated co-contamination rates of HIV, HBV, and HCV. ${ }^{8}$ The spread of blood borne hepatitis 
and HIV infections is on the rise and keeping this in mind this study was designed to determine the frequency of Hepatitis B, Hepatitis C and HIV among patients of Intravenous Drug Use (IDU), so that strategies could be made and preventive measures could be taken to control drug use and so on to prevent the spread of Hepatitis HIV, HBV, and HCV infections.

\section{MATERIAL AND METHODS}

This is a descriptive, cross-sectional study conducted at the Department of Psychiatry \& Behavioral Sciences, Jinnah Postgraduate Medical Centre, Karachi, from $5^{\text {th }}$ Aug 2016 to $5^{\text {th }}$ Feb 2017. The sample size of this study was 280 calculated through standard sample size calculation formula. The clients who gave consent to participate in study, both males and females between ages of 18 to 65 years and using drugs through injectable routes were enrolled. Those clients who were non-co-operative, who were already positive cases before consulting at centre or those who have history of un-protected sexual contact were excluded from study. Ethical approval was taken from institute and informed consent regarding the inclusion of patient's data in this study was obtained after assuring them of confidentially and their right to withdraw from study at any time without even mentioning any reason. A semi-structured proforma containing demographic data, type and route of substance use, presence of HIV, HBV or HCV were filled in with clients' information. The data was analyzed on SPSS version 20.

\section{RESULTS}

A total of 280 clients, diagnosed cases of Drug Injection Users (DIUs) were included in this study.
Most of the patient's age was between 19 to 38 years. The average age of the patients was 32.26 \pm 9.83 years. Out of 280 cases majority 256 (91.4\%) were male and $24(8.6 \%)$ were female. Among 280 cases, 142 (50.7\%) were married, $108(38.6 \%)$ were single, $20(7.1 \%)$ were widow and $10(3.6 \%)$ were divorced/separated. Majority of patients were preliterate, about $48.5 \%$ were preliterate and $24.6 \%$ were educated till primary. Only $12.5 \%$ were educated up to middle and $7.1 \%$ were matriculated. Out of 280 cases $32.5 \%$ were unskilled professionals who work as laborers, $21.4 \%$ were jobless and doing nothing but using substances. Household substance users were $10.4 \%$ and $11.1 \%$ were those people who had job but were not working. Some of the clients were brought by family $47.1 \%$, some came by themselves $27.5 \%$ and some $25.4 \%$ were referred by friends. Among 280 patients majority 124 (44.3\%) were the cases of Opioids use followed by multiple substances 123 (43.9\%), the cases of Benzodiazepine were $11.1 \%$ and Cannabis were only $0.7 \%$. Most of patients $67.5 \%$ were belonging to lower socioeconomic class whose monthly income was less than 15,000 per month, $27.5 \%$ were earning between 15,000 to 30,000 per month and only $5 \%$ were having monthly income of above 30,000 . Among 280 cases of substance users Hepatitis $\mathrm{C}(\mathrm{HCV})$ was present in $16.8 \%$ followed by Hepatitis B (HBV) as $7.9 \%$ and HIV as $3.2 \%$.

\begin{tabular}{|l|c|c|}
\hline \multicolumn{1}{|c|}{ Presence of } & Frequency & $\%$ \\
\hline None & 180 & 64.3 \\
\hline HCV & 47 & 16.8 \\
\hline HBV & 22 & 7.9 \\
\hline HIV & 9 & 3.2 \\
\hline Total & 280 & 100.0 \\
\hline & Table-I. Prevalence of HCV, HBV and HIV \\
\hline
\end{tabular}

\begin{tabular}{|c|c|c|c|c|c|c|}
\hline & & \multicolumn{3}{|c|}{ Socioeconomic Class } & \multirow[b]{2}{*}{ Total } & \multirow[b]{2}{*}{ P-value } \\
\hline & & $\begin{array}{l}\text { Less than } 15000 \\
\text { per Month }\end{array}$ & $\begin{array}{c}15 \text { to } 30 \text { Thousand } \\
\text { per Month }\end{array}$ & $\begin{array}{c}30,000 \text { to } 100,000 \\
\text { per Month }\end{array}$ & & \\
\hline HIV & No & 175 & 71 & 12 & 258 & \multirow{2}{*}{0.653} \\
\hline \multicolumn{2}{|l|}{ Total } & 189 & 77 & 14 & 280 & \\
\hline \multirow{2}{*}{ HBV } & No & 168 & 64 & 13 & 245 & \multirow[b]{2}{*}{0.358} \\
\hline & Yes & 21 & 13 & 1 & 35 & \\
\hline \multirow{2}{*}{$\mathrm{HCV}$} & No & 145 & 57 & 9 & 211 & \multirow{3}{*}{0.553} \\
\hline & Yes & 44 & 20 & 5 & 69 & \\
\hline \multicolumn{2}{|l|}{ Total } & 189 & 77 & 14 & 280 & \\
\hline
\end{tabular}

Table-II. Association of HIV, HBV and HCV with Socioeconomic class 


\begin{tabular}{|c|c|c|c|c|c|c|c|}
\hline & \multicolumn{4}{|c|}{ Type of Substance use } & \multirow{2}{*}{ Total } & \multirow{2}{*}{ P-value } \\
\hline & & Cannabis & Opioids & Benzodiazepine & Multiple substances & & \\
\hline \multirow{2}{*}{ HIV } & No & 2 & 115 & 30 & 111 & 258 & \multirow{3}{*}{0.623} \\
\hline & Yes & 0 & 9 & 1 & 12 & 22 & \\
\hline \multicolumn{2}{|l|}{ Total } & 2 & 124 & 31 & 123 & 280 & \\
\hline \multirow{2}{*}{ HBV } & No & 2 & 110 & 30 & 103 & 245 & \multirow{3}{*}{0.214} \\
\hline & Yes & 0 & 14 & 1 & 20 & 35 & \\
\hline \multicolumn{2}{|l|}{ Total } & 2 & 124 & 31 & 123 & 280 & \\
\hline \multirow{2}{*}{$\mathrm{HCV}$} & No & 1 & 95 & 24 & 91 & 211 & \multirow{3}{*}{0.803} \\
\hline & Yes & 1 & 29 & 7 & 32 & 69 & \\
\hline \multicolumn{2}{|l|}{ Total } & 2 & 124 & 31 & 123 & 280 & \\
\hline \multicolumn{8}{|c|}{ Table-III. Association of HIV, HBV and HCV with type of substance use } \\
\hline & & \multicolumn{3}{|c|}{ Duration of Substance Use } & Total & \multirow{2}{*}{\multicolumn{2}{|c|}{ P-value }} \\
\hline & & Less $\mathrm{T}$ & n Two Year & More Than Two Year & IOtal & & \\
\hline \multirow{2}{*}{ HIV } & No & & 46 & 212 & 258 & \multirow{3}{*}{\multicolumn{2}{|c|}{0.110}} \\
\hline & Yes & & 1 & 21 & 22 & & \\
\hline \multicolumn{2}{|l|}{ Total } & \multicolumn{2}{|c|}{47} & 233 & 280 & & \\
\hline \multirow{2}{*}{ HBV } & No & & 13 & 202 & 245 & \multirow{3}{*}{\multicolumn{2}{|c|}{0.365}} \\
\hline & Yes & & 4 & 31 & 35 & & \\
\hline \multicolumn{2}{|l|}{ Total } & \multicolumn{2}{|c|}{47} & 233 & 280 & & \\
\hline \multirow{2}{*}{$\mathrm{HCV}$} & No & & 41 & 170 & 211 & \multirow{3}{*}{\multicolumn{2}{|c|}{0.038}} \\
\hline & Yes & & 6 & 63 & 69 & & \\
\hline \multicolumn{2}{|l|}{ Total } & \multicolumn{2}{|c|}{47} & 233 & 280 & & \\
\hline
\end{tabular}

Table-IV. Association of HIV, HBV and HCV with duration of substance use

\section{DISCUSSION}

This study has shown the frequency of Hepatitis C, Hepatitis B and HIV as $16.8 \%, 7.9 \%$ and $3.2 \%$ respectively. The frequency of HCV is $16.9 \%$ while a national survey conducted in 2005 had revealed HCV frequency $88 \%$ and $91 \%$ in IDUs of Karachi (Sindh) and Lahore (Punjab), respectively ${ }^{9}$, the large difference could be due to, this is a hospital based study and those who are already diagnosed may have not approached for treatment and the population taken is only those who have visited for consultation purpose and the previous study was of survey type, however further research regarding this is needed. Another study conducted in 2003 evidenced HCV frequency of $93 \%$ and $75 \%$ among injection drug use (IDUs) of Lahore (Punjab) and Quetta (Baluchistan), respectively. While Achakzai et al in a smaller study in 2004 showed HBV, $\mathrm{HCV}$, and HIV prevalence of $6 \%, 60 \%$, and $24 \%$ respectively in the IDUs of Quetta ${ }^{10}$, while this study has shown the prevalence of HBV, HCV and HIV as $7.9 \%, 16.8 \%, 3.2 \%$ respectively, which is quite low rate but the reason could be that this is one centre based study and the finding in this study may be quite incidental. Researches from Lahore and Larkana had assessed correlates of injection drugs use and HIV transmission. They had searched risk factors such as presence of an IDU friend, reuse of same syringe, cost of current drug and poly drug use. ${ }^{11}$ In this study the HIV was prevalent as $3.2 \%$ with history of friend using injectable substance together. Another study within Pakistan has revealed the prevalence of Hepatitis B antigen $2.4 \%$ and Hepatitis C antibodies $3.0 \%{ }^{12}$, which is low as comparable to our study but again the difference is of methodology and population studied.

In another study at Eastern Anatolia, Turkey in 2015 has observed the frequencies of HBsAg and anti-HCV among drug addicts were $2.6 \%{ }^{13}$ and $9.4 \%$, respectively which is comparable with our study, in the said research, no HIV positive was found among drug users but in our scenario the HIV is more prevalent. A study from Quetta Pakistan has shown the frequency of $\mathrm{HBV}, \mathrm{HCV}$ and HIV among IDUs as $43 \%, 44.7 \%$ and $0.33 \%{ }^{14}$ respectively, which is somehow comparable with ours though the morbidity of HBV and HCV in our 
study is lower than that. In high risk groups like drug abusers, particularly injection drug users (IDUs) a survey conducted by NACP shows $0.5 \%$ sero-prevalence of HIV and $91.8 \%$ seroprevalence of HCV in IDUs in Lahore and a seroprevalence of $23.3 \%$ of HIV and $88 \%$ of $\mathrm{HCV}$ in Karachi during 2005. ${ }^{15}$ However in current study, the frequency of $\mathrm{HBV}$ infection is $9.7 \%$ and $\mathrm{HCV}$ is $16.9 \%$ which is less than that detected at Karachi and Lahore previously, in this regard further research is warranted.

\section{Copyright@ 22 Dec, 2018.}

\section{REFERENCES}

1. http://www.drugabuse.gov/sites/default/files/ mediaguide_web.pdf.

2. Burt RD, Hagan H, Garfein RS, Sabin K, Weinbaum C, Thiede $H$. Trends in hepatitis $B$ virus, hepatitis $C$ virus, and human immunodeficiency virus prevalence, risk behaviors, and preventive measures among Seattle injection drug users aged 18-30 years, 1994-2004. J Urban Health.2007; 84(3):436-54.

3 . Bertoletti A, Gehring AJ. Immune therapeutic strategies in chronic hepatitis B virus infection: virus or inflammation control? PLOS Pathog, 2013; 9(12):784.

4. Clark F. Global drug policy fuels hepatitis $\mathbf{C}$ epidemic, report warns. Lancet. 2013; 381(9881):1891.

5. Bekolo CE, Nguena MB, Ewane L, Bekoule PS, Kollo $B$. The lipid profile of HIV-infected patients receiving antiretroviral therapy in a rural Cameroonian population. BMC Public Health. 2014; 14:236.

6. Tahaei SM, Mohebbi SR, Azimzadeh P, Vahedi M, Almasi $S$, Romani $S$, et al. Frequency of HIV and HCV CoInfections in Chronic HBV Patients Referred to Taleghani Hospital, Tehran, Iran from 2006 to 2010. Hepat Mon, 2011; 11(12):993-6.
7. Garfein R, Vlahov D, Galai N, et al. Viral infections in short-term injection drug users: The prevalence of the hepatitis C, hepatitis B, human immunodeficiency, and human T-lymphotropic viruses. Am J Public Health.1996; 86:655-61.

8. Zeldis J, Jain S, Kuramoto I. Seroepidemiology of viral infections among intravenous drug users in northern California. West J Med, 1992; 156:30-35.

9. Achakzai M, Kassi M, Kasi PM. Seroprevalences and co-infections of HIV, hepatitis C virus and hepatitis B virus in injecting drug users in Quetta, Pakistan. Trop Doct 2007; 37:43-5.

10. Kuo I, Ul-Hasan S, Zafar T, Galai N, Sherman SG, Strathdee SA. Factors associated with recent onset injection drug use among drug users in Pakistan. Subst Use Misuse 2007; 42:853-70.

11. Rehman NU, Emmanuel F, Akhtar S. HIV transmission among drug users in Larkana, Pakistan. Trop Doct 2007; 37:58-9.

12. Alia AS, Rafe MJ, Donahueb, Qureshic H, Vermund SH. Hepatitis B and hepatitis C in Pakistan: Prevalence and risk factors. Int $\mathrm{J}$ Infect Dis, 2009; 13(1):9-19.

13. Karabulut N, Bulut $Y$, Telo S. Frequency of hepatitis B and $C$ viruses, and HIV among drug addicts in the Eastern Anatolia, Turkey. Jundishapur J Microbiol, 2015; 8(8):19698.

14. Abbasi S, Faqir F, Khan S, Zaidi SK, Ahmed SQ, Satti MA. A serological study of hepatitis $c$ and human Immunodeficiency virus in a cohort of intravenous Drug users in Quetta, Balochistan. JPMI, 2009, 23(1)3-6.

15. Rehan N, Bokhari A, Nizamani NM, Jackson D, Naqvi HR, Qayyum K, Mansoor S, Muzaffar R. National study of reproductive tract infections among high risk groups of Lahore and Karachi. J Coll Physicians Surg Pak. 2009 Apr 1;19(4):228-31.

\begin{tabular}{|c|c|c|c|}
\hline \multicolumn{4}{|c}{ AUTHORSHIP AND CONTRIBUTION DECLARATION } \\
\hline Sr. \# & Author-s Full Name & Contribution to the paper & Author=s Signature \\
\hline 1 & Muhammad llyas Jat & $\begin{array}{l}\text { Concept, Design, Statistical } \\
\text { analysis \& Editing of manuscript. } \\
\text { Data collection, Result writing } \\
\text { and manuscript writing. }\end{array}$ \\
\hline 2 & Ghulam Rasool Rind & \begin{tabular}{l} 
Gaty \\
\hline
\end{tabular} \\
\hline
\end{tabular}

